University of Nebraska - Lincoln

DigitalCommons@University of Nebraska - Lincoln

Agronomy \& Horticulture - Faculty Publications

Agronomy and Horticulture Department

8-1968

\title{
A Water-Soluble Factor in Melilotus officinalis Leaves Which Stimulates Feeding by the Adult Sweetclover Weevil
}

\author{
W. R. Akeson \\ University of Nebraska-Lincoln \\ Herman J. Gorz \\ United States Department of Agriculture \\ Francis A. Haskins \\ University of Nebraska-Lincoln, fhaskins@neb.rr.com \\ G. R. Manglitz \\ United States Department of Agriculture
}

Follow this and additional works at: https://digitalcommons.unl.edu/agronomyfacpub

Part of the Plant Sciences Commons

Akeson, W. R.; Gorz, Herman J.; Haskins, Francis A.; and Manglitz, G. R., "A Water-Soluble Factor in Melilotus officinalis Leaves Which Stimulates Feeding by the Adult Sweetclover Weevil" (1968). Agronomy \& Horticulture -- Faculty Publications. 210.

https://digitalcommons.unl.edu/agronomyfacpub/210

This Article is brought to you for free and open access by the Agronomy and Horticulture Department at DigitalCommons@University of Nebraska - Lincoln. It has been accepted for inclusion in Agronomy \& Horticulture -Faculty Publications by an authorized administrator of DigitalCommons@University of Nebraska - Lincoln. 


\title{
A Water-Soluble Factor in Melilotus officinalis Leaves Which Stimulates Feeding by the Adult Sweetclover Weevil ${ }^{1,2}$
}

\author{
W. R. Akeson, H. J. Gokz, F. A. HIaskins, and G. R. Manglitzi, 4
}

\begin{abstract}
Akeson ct al, (196\%) reported that the water-methanol ahase of a water-methanol-chloroform extract, obtained from leaves of Melilouss officinalis L. Lam. (variety Goldtop), stimulated extensive feeding by the sweetclover wee. ipil, Sitona cylindricollis (Fähraeus), on bioassay disks prepared from swectclover roots. Subsequent studies ${ }^{5}$ have ghown that a hot-water extract will elicit a similar reponse. When disks were treated only with the solvent used in extraction, an almost negligible amount of feeding was obtained. Thus, leaves of Goldtop sweetclover apparently contain 1 or more watcr-soluble feeding stimulants. Beck (1965) defined a feeding stimulant as a stimulus tending to promore continuous fceding. The present paper describes the feeding stimulant from a hot-water extract of Goldtop sweetclover leaves.

Materials aNd Methods,-Fresh young leaves of green. house-grown Goldtop sweetclover plants were weighed, washed with distilled water, dropped into boiling water (10 ml/g of fresh tissue) in a glass beaker, and boiled for $5 \mathrm{~min}$. The hot mixture was homogenized for $2 \mathrm{~min}$ in a blender and then boiled for an additional $5 \mathrm{~min}$. The homogenatc was cooled to room temperature and centri. fuged at $2400 \mathrm{~g}$ for $30 \mathrm{~min}$. The supernatant liquid was fiash evaporated at $40^{\circ} \mathrm{C}$ to a volume of $5 \mathrm{ml} / \mathrm{g}$ of original dity plant matcrial. The hot water extract was stored at $-20^{\circ} \mathrm{C}$ until used. Occasionally a precipitate appeared in the extract after freczing and thawing. In such instances the extract was contrifuged as before and the precipitate was discarded.
\end{abstract}

1 Coleoptera: Curculionidae. 'A cooperative investigation between the Nebraska Agriculmology Research Division and Grops Research Division, Agr. Res. Serv.' USDA, supported in part by ARS Grant no. 12-14-100. 8027 (33) . Contribution no. 292 of Department of Entomology, University of Nebraska. Published with approval of the Directo as Paper no. 222\% Journal Scries, Nebraska Agricultural Experiment Station. Accepted for publication March 6, 1968 .

Assistant l'rofessor of Agronomy, University of Nebraska; Research Geneticist, Grops Research Division. ARS, USDA; Profesor of Agronony. University of Nebraska: and Research Encomologist, Entomology Res. Div,, ARS, USDA, I,incoln, Neb., respectively.

The technical assistance of Henry J. Stevens, Entomology $R e$ search Division, Agr. Res. Serv., USD,A, and Gary I. Beland, Graduate Rescirch Assistant. I)epartment of Entomology, UniWW of Neliska, is gratedilly ach nowledged.

W. R. Akcson, unpublisued data.
Hot-water extracts were cluromatographed on $181 / 2 \times$ $281 / 2 \mathrm{~cm}$ sheets of Whatman no. 3 filter paper. On each sheet, two $0.1-\mathrm{ml}$ portions of extract were applied to an 18-cm base line which was $2.5 \mathrm{~cm}$ from the bottom of the chromatogram. The 7 solvents listed in Table 1 were used to develop the chromatograns. When the solvent had ascended $15 \mathrm{~cm}$ above the base line, the chromatograms were air dried at room temperature, and each sheet was cut into 6 strips of equal width (approximately 2.5 $\mathrm{cm}$ ) parallel to the base line. In some later experiments strips approximately $1.5 \mathrm{~cm}$ wide were cut from the region containing stimulant activity to locate the active factor more precisely. The strips were eluted with distilled water in an apparatus similar to that used in descending chromatography. Elution was continued until $0.5 \mathrm{ml}$ of eluate had been collected from each strip.

A bioassay essentially like that described by Akeson et al. (1967) was used to test the eluates for components that influenced feeding by the sweetclover wcevil. live root disks were treated with $0.15 \mathrm{ml}$ of eluate. I.ittle feeding occurred on disks treated with water or nonactive fractions; thus, the presence of a feeding stimulant was indicated in those disks that were appreciably consumed.

Results and Concl.usions.-Bioassays for the detection of active factors were conducted with the 6 eluates obtained from each of 7 different chromatographic systems. Table 1 presents results expressed as the average percentage disk area consumed from 5 disks used for each treat. ment. With each of the solvent systems, feeding-stimulant activity appeared to be confined to a single area of the chromatogram. In several of the systems, activity was divided more or less evenly between 2 adjacent sections, but in no case was 1 section (or more) of low feeding-stimulant activity interposed between 2 sections of high activity. Thus, available evidence supports the conclusion that leaves of Goldtop sweetclover contain a single watersoluble feeding stimulant. This factor has been designated Stimulant A.

A more precise determination of the $R_{1}$ value for Stimulant $A$ has been accomplished by re-chromatographing the eluates and using narrower band widths cut from the general region of activity. With partially purified fractions, $R_{1}$ values tend to be somewhat higher than

6 Mention of a proprietary product does not necessarily imply its endorsement by the USDA.

Table 1.-Assay of chromatographic fractions for feeding-stinulant activity. Data are expressed as average percentage disk area consumed from 5 disks used in each treatment.

\begin{tabular}{|c|c|c|c|c|c|c|c|}
\hline \multirow[b]{2}{*}{$\mathbf{R}_{\mathbf{t}}$ range } & \multicolumn{7}{|c|}{ Solvent systems ${ }^{b}$} \\
\hline & $\begin{array}{c}\mathrm{i}-\mathrm{PrOH} 8 \\
\mathrm{NH}_{4} \mathrm{OH}_{1} \\
\mathrm{H}_{2} \mathrm{Ol}_{1}\end{array}$ & $\begin{array}{c}\mathrm{i}-\mathrm{PrOH} 8 \\
\mathrm{NH}_{2} \mathrm{OH} \\
\mathrm{H}_{z} \mathrm{O} 3\end{array}$ & $\begin{array}{c}\text { i-PrOH } 20 \\
\text { HAc } 4 \\
\mathrm{H}_{2} \mathrm{O} 15\end{array}$ & $\begin{array}{c}n-\text {-BuOH } 5 \\
\text { HAc } 1 \\
\mathrm{H}_{9} 04 \\
\text { (upper } \\
\text { phase) }\end{array}$ & $\begin{array}{c}n-\mathrm{BuOH} 5 \\
\mathrm{EtOH}_{1} \\
\mathrm{H}_{2} \mathrm{O}_{2}\end{array}$ & $\begin{array}{c}\text { EtAc } 6 \\
\text { HAc } 2 \\
\mathrm{H}_{3} \mathrm{O} 5 \\
\text { (upper } \\
\text { phase) }\end{array}$ & $\mathrm{MeOH}$ \\
\hline \multirow{7}{*}{$\begin{array}{l}0.00-0.17 \\
.17-.33 \\
.33-.50 \\
.50-.67 \\
.67-.83 \\
.89-1.00 \\
A \text { pproximate } \mathrm{R}_{t} \\
\text { of stimulant }\end{array}$} & $0 . \bar{j}$ & 2.0 & 0.7 & 1.7 & 70.9 & 72.0 & 3.7 \\
\hline & $\begin{array}{r}0.1 \\
+2.5\end{array}$ & 3.0 & $\begin{array}{l}0.6 \\
1.0\end{array}$ & $\begin{array}{r}1.1 \\
43.4\end{array}$ & $\begin{array}{l}70.9 \\
51.1\end{array}$ & 14.4 & 52.0 \\
\hline & 39.2 & 39.8 & 2.7 & 7.5 & 9.0 & 0.3 & 60.0 \\
\hline & 2.0 & 38.0 & 59.3 & 4.9 & 1.0 & 6.2 & 0.0 \\
\hline & .7 & 2.7 & 31.5 & 0.7 & 13.3 & 8.3 & .0 \\
\hline & 2.7 & 6.0 & 5 & 2.7 & 1.0 & 4.6 & .0 \\
\hline & 0.31 & 0.50 & 0.65 & 0.25 & 0.25 & 0.10 & 0.43 \\
\hline
\end{tabular}


Table 2.-Refincment of $R_{f}$ determination for the feeding stimulant. Solvent: isopropyl alcohol-acetic acid-water $(20: 4: 15, v / v / v)$.

\begin{tabular}{cc}
\hline $\mathrm{R}_{\mathrm{f}}$ range & $\%$ avg, disk area consumed" \\
\hline Water blank & 0.0 \\
$0.53-0.62$ & 2.3 \\
$.62-0.69$ & 6.3 \\
$.69-.75$ & 49.0 \\
$.75-.85$ & 9.1
\end{tabular}

: 15 -cm ascent on Whatman no. 3 filter paper.

1) Arerage of 5 disks/treatment. those observed wilh a crude preparation. Table 2 shows results obtained from 1 such series of strips cut from chromatogram developed in the isopropyl alcohol-acetic acid-watex $(20: 4: 15 \mathrm{v} / \mathrm{v} / \mathrm{y})$ solvent. In this example, actiy ity was confined primarily to the band extending from $\mathrm{R}$ 0.69 to 0.75 ; this fact indicated an $R_{f}$ of 0.72 for Stimulain $A$ in this solvent system. This value compares with $a$ preliminary estimate of. 0.65 (Table 1).

\section{REFER ENCES CTTED}

Akeson, W. R., G. R. Manglitz, H. J. Gorx, and T. A. Haskins. 1967. A bioassaly for detceting compounds which stimulate or deter feeding by the sweetclove wecvil. J. Econ. Entomol, 60: 1082-4.

Beck, S. D. 1965. Resistance of plants to insects. Annü Rer, Entomol. 10: 207-32. 